\title{
PENINGKATAN HASIL BELAJAR MELALUI STRATEGI \\ PEMBELAJARAN LANGSUNG (DIRECT INSTRUCTION) \\ MATA PELAJARAN BAHASA INDONESIA \\ KELAS V SD NEGERI 163086 TEBING TINGGI
}

\author{
Elmaida* \\ Surel: elmaidaspd13@gmail.com
}

\begin{abstract}
The target of this study is Class V students of SD Negeri 163086 Tebing Tinggi 2015/2016 Academic Year. Data obtained in the form of formative test results, observation sheets of teaching and learning activities. From the results of the analysis it was found that students' learning achievement had increased from pre-cycle to cycle II, namely prasiklus (69.69\%), cycle II (78.78\%) and cycle II (90.90\%). The conclusion of this study is that the learning strategy through direct instruction can have a positive effect on the learning outcomes of Class V students at SD Negeri 163086 Tebing Tinggi, and this learning model can be used as an alternative to learning Indonesian.
\end{abstract}

Keywords: Language, Results, Learning

\begin{abstract}
ABSTRAK
Sasaran penelitian ini adalah siswa Kelas V SD Negeri 163086 Tebing Tinggi Tahun Pelajaran 2015/2016. Data yang diperoleh berupa hasil tes formatif, lembar observasi kegiatan belajar mengajar. Dari hasil analis didapatkan bahwa prestasi belajar siswa mengalami peningkatan dari prasiklus sampai siklus II yaitu, prasiklus $(69,69 \%)$, siklus II $(78,78 \%)$ dan siklus II $(90,90 \%)$. Simpulan dari penelitian ini adalah strategi pembelajaran melalui pembelajaran langsung (direct instruction) dapat berpengaruh positif terhadap hasil belajar siswa Kelas V SD Negeri 163086 Tebing Tinggi, serta model pembelajaran ini dapat digunakan sebagai salah satu alternatif pembelajaran Bahasa Indonesia.
\end{abstract}

Kata Kunci: Bahasa, Hasil, Pembelajaran

\section{PENDAHULUAN}

Fokus utama tujuan
pengajaran Bahasa Indonesia
meliputi empat aspek ketrampilan
berbahasa yaitu ketrampilan menyimak, ketrampilan berbicara, ketrampilan membaca dan menulis. Keempat aspek kemampuan berbahasa tersebut saling berkaitan erat, sehingga merupakan satu kesatuan dan bersifat hirarkis, artinya ketrampilan berbahasa yang satu akan mendasari ketrampilan berbahasa yang lain.

Kemampuan mengajar guru berperan penting dalam mensukseskan proses

belajar mengajar. Seorang guru harus mampu mengukur kemampuan anak terhadap materi 
Elmaida: Peningkatan Hasil Belajar...

yang diajarkan. Pada akhirnya proses belajar mengajar guru memberi latihan soal dan pengerjaan soal. Untuk memantapkan penguasaan materi pada pelajaran Bahasa Indonesia.

Kualitas pembelajaran dapat dilihat dari segi proses dan hasil pembelajaran. Dari segi proses pembelajaran dikatakan berhasil apabila seluruhnya atau setidak-tidaknya sebagian besar (75\%) peserta didik terlibat secara aktif, baik fisik, mental maupun sosial dalam proses pembelajaran disamping menunjukkan kegairahan belajar tinggi, semangat belajar besar dan rasa percaya diri yang tinggi.

Kemampuan membaca nyaring siswa SD Negeri 163086 Tebing Tinggi belum mencapai Kriteria Ketuntasan Minimal yanga di tetapkan yaitu sebesar 70 dan indkator keberhasilan $85 \%$ jumlah siswa mencapai KKM. Hal ini dapat dilihat dari hasil belajar siswa pada kondisi awal siswa yang dapat membaca nyaring dan hasil evaluasi awal yang mencapai nilai KKM hanya 23 siswa yang tuntas . Dari 33 siswa kelas V SD Negeri 163086 Tebing Tinggi sebesar $69,69 \%$ tuntas secara klasikal dan 30,31 \% dinyatakan belum tuntas.

Dengan memperhatikan nilai ulangan siswa yang rendah diatas maka agar dapat meningkatkan kemampuan siswa terhadap materi pelajaran yaitu bercerita guru harus melakukan perbaikan pembelajaran dengan menggunakan media gambar dan proses perbaikan pembelajaran serta dilakukan observasi maupun diskusi observasi dengan teman sejawat.

\section{METODE PENELITIAN}

Metode direct instruction mengarah pada dunia akademis yaitu metode pengajar yang menggunakan materi yang terstruktur dan berkelanjutan. Pada metode ini tujuan pada aktivitas pengajaran adalah tingkat pemahaman konsep pelajaran bagi siswa, alokasi waktu untuk instruksi cukup dan kontinue, isi materi berkembang, performance siswa dimonitor dan feedback pada siswa diberikan segera dan berorientasi akademis.Oleh karena itu diharapkan melalui metode Direct Instruction dapat meningkatkan hasil belajar bahasa Indonesia siswa di kelas V SD Negeri 163086 Tebing Tinggi tahun ajaran 2015/2016.

Tempat penelitian adalah tempat yang digunakan dalam melakukan penelitian untuk memperoleh data yang diinginkan. Penelitian ini bertempat di SD Negeri 163086, Jl. Pendidikan Kec. Tebing Tinggi Kota, Kota Tebing Tinggi Tahun Pelajaran 2015/2016. Sesuai dengan jenis penelitian yang dipilih, yaitu penelitian tindakan, maka penelitian ini menggunakan model 
penelitian tindakan dari Kemmis dan Taggart (dalam Sugiarti, 1997: 6), yaitu berbentuk spiral dari siklus yang satu ke siklus yang berikutnya. Setiap siklus meliputi planning (rencana), action (tindakan), observation (pengamatan), dan reflection (refleksi). Langkah pada siklus berikutnya adalah perncanaan yang sudah direvisi, tindakan, pengamatan, dan refleksi. Sebelum masuk pada siklus 1 dilakukan tindakan pendahuluan yang berupa identifikasi permasalahan.

Instrumen Penelitian (Alat Pengumpulan Data)Alat pengumpul data dalam penelitian ini adalah tes yang disusun oleh Guru yang fungsinya adalah: (1) Untuk menentukan seberapa baik siswa telah menguasai bahan pelajaran yang telah diberikan dalam waktu tertentu;(2) Untuk menentukan apakah suatu tujuan telah tercapai; dan (3) Untuk memperoleh suatu nilai (Arikunto, Suharismi, 2002: 19). Sedangkan tujuan dari tes adalah untuk mengetahui ketuntasan belajar siswa secara individual maupun secara klasikal. Disamping itu untuk mengetahui letak kesalahankesalahan yang dilakukan siswa sehingga dapat dilihat dimana kelemahannya, khususnya pada pokok bahasan materi ajar yang belum tercapai. Untuk memperkuat data yang dikumpulkan, maka juga digunakan metode observasi (pengamatan) yang dilakukan oleh teman sejawat untuk mengetahui dan merekam aktifitas Guru dan siswa dalam proses belajar mengajar.

Analisis ini dihitung dengan menggunakan statistik sederhana yaitu :

1. Untuk menilai ulangan atau tes formatif Peneliti melakukan penjumlahan nilai yang diperoleh siswa, yang selanjutnya dibagi dengan jumlah siswa yang ada di kelas tersebut sehingga diperoleh rata-rata tes formatif dapat dirumuskan :

$$
\mathrm{X}=\frac{\Sigma x}{\Sigma \mathrm{N}}
$$

Dengan $: \mathrm{X}=$ Nilai ratarata

nilai siswa

$$
\sum X=\text { Jumlah semua }
$$

$$
\sum \mathrm{N}=\text { Jumlah siswa }
$$

2. Untuk ketuntasan belajar Ada dua kategori ketuntasan belajar yaitu secara perorangan dan secara klasikal. Berdasarkan petunjuk pelaksanaan belajar mengajar kurikulum 1994 (Depdikbud, 1994), yaitu seorang siswa telah tuntas belajar bila telah mencapai skor 70, dan kelas disebut tuntas belajar baik dikelas tersebut terdapat $85 \%$ yang telah mencapai daya serap lebih dari atau sama dengan 70. Untuk menghitung presentase ketuntasan belajar digunakan rumus sebagai berikut: 
Elmaida: Peningkatan Hasil Belajar...

$\mathrm{P}=\frac{\Sigma \text { Siswa.yang.tuntas.belajar }}{\Sigma \text { Siswa }} \mathrm{x}$

$100 \%$

3. Untuk lembar observasi

Lembar observasi pengelola metode pembelajaran pembelajaran langsung (direct instruction). Untuk menghitung lembar observasi pengelolaan metode pembelajaran metode direct instruction digunakan rumus sebagai berikut :

$$
\mathrm{X}=\frac{P 1+P 2}{2}
$$

Dimana $\mathrm{P} 1=$ Pengamat 1 dan $\mathrm{P} 2=$ Pengamat 2

a. Lembar observasi aktifitas Guru dan siswa

Untuk menghitung lembar observasi aktifitas Guru dan siswa digunakan rumus sebagai berikut :

$\%=\frac{x}{\Sigma x} \times 100 \%$ dengan

$\mathrm{X}=\int \frac{\text { Jumah.hasil.pengamatan }}{\text { Jumlah.pengamatan }}$

$=\frac{P 1+P 2}{2}$

Dimana: $\%=$ Presentase pengamatan

$$
\begin{array}{ll}
\mathrm{X} & =\text { Rata-rata } \\
\sum \mathrm{x} & =\text { Jumlah rata-rata } \\
\mathrm{P} 1 & =\text { Pengamat } 1 \\
\mathrm{P} 2 & =\text { Pengamat } 2
\end{array}
$$

Indikator Keberhasilan

Penelitian ini dapat dikatakan berhasil dan tidak perlu dilanjutkan kepada siklus berikutnya apabila hasil dari tes siswa yang berjumlah 33 orang telah sesuai dengan KKM yang ditentukan yaitu 70 atau tingkat ketuntasan kelas diatas 85 $\%$ dari 33 siswa. Selain itu jika dilihat dari pengelolaan pembelajaran, yaitu persentase pengelolaan pembelajaran yaitu aktivitas guru dan aktivitas siswa diatas $85 \%$.

\section{SIKLUS I}

dapat dijelaskan disiklus I bahwa dengan menerapkan metode pembelajaran langsung (direct instruction) pada materi pelajaran diperoleh nilai rata-rata hasil belajar siswa adalah 75,75 dan ketuntasan belajar mencapai $78,78 \%$ atau ada 26 siswa dari 33 siswa sudah tuntas belajar. Hasil tersebut menunjukkan bahwa pada siklus pertama secara klasikal siswa belum tuntas belajar, karena siswa yang memperoleh nilai $\geq 70$ hanya sebesar 78,78 \% lebih kecil dari persentase ketuntasan yang dikehendaki yaitu sebesar $85 \%$. Meskipun demikian, terjadi peingkatan hasil belajar siswa dari pra siklus ke siklus I walaupun hasilnya belum sesuai dengan indikator keberhasilan. Dengan penerapan metode direct instruction dapat meningkatkan hasil belajar siswa Kelas V SD Negeri 163086. Nilai yang masih rendah disebabkan karena siswa belum terbiasa dengan metode diect instruction dan siswa perlu 
beradaptasi dengan metode tersebut. Selain itu guru kurang memanfaatkan media yang mendukung pembelajaran sehingga siswa kurang tertarik dalam mengikuti pembelajaran, serta guru kurang melibatkan semua siswa aktif dalam mengikuti pembelajaran. Kenyataan tersebut mengakibatkan siswa hanya pasif dan tidak fokus dalam pembelajaran sehingga hasil belajar siswa renda Hasil tersebut menggambarkan perlu adanya suatu tahapan selanjutnya untuk memperbaiki hasil belajar agar target yang diharapkan dapat tercapai.

\section{SIKLUS II}

diperoleh nilai rata-rata prestasi belajar siswa adalah 76,81 dan ketuntasan belajar mencapai 90,90\% atau ada 30 siswa dari 33 siswa sudah tuntas belajar. Hasil ini menunjukkan bahwa pada siklus II ini ketuntasan belajar secara klasikal telah mengalami peningkatan lebih baik dari siklus I. Adanya peningkatan hasil belajar siswa ini karena siswa-siswa telah mulai terbiasa dengan metode pembelajaran direct instruction yang diberikan oleh guru sehingga mereka terbiasa berdiskusi dengan aktif di dalam kelompok mereka masing masing dalam upaya meningkatkan pemahaman mereka terhadap materi yang disampaikan. Dari segi hasil belajar, siswa yang mendapatkan nilai 70 ke atas, sudah mencapai 30 siswa dan nilai rata-rata kelas juga sudah mengalami kenaikan. Dari hasil perhitungan, nilai rata-rata kelas mencapai 76,81 . Nilai ini sudah di atas nilai standar. Sehingga dianggap pembelajaran sudah mencapai titik ketuntasan, meskipun belum $100 \%$ siswa dinyatakan tuntas belajar.Maka dari itu tidak perlu dilanjutkan ke siklus selanjutnya karena sudah dianggap berhasil dan memenuhi kriteria penilaian secara klasikal.

\section{HASIL DAN PEMBAHASAN}

Secara garis besar kegiatan belajar mengajar dengan metode pembelajaran langsung (direct instruction) sudah dilaksanakan dengan baik, walaupun belum semua siswa yang tuntas belajar. Pada siklus I keaktifan siswa selama pembelajaran mencapai $71 \%$ dengan jumlah siswa tuntas sebanyak 26 siswa dan persentase ketuntasan belajar siswa 78,78\%.

Pengamatan terhadap kompetensi belajar siswa pada siklus I dengan tindakan melalui model pembelajaran langsung (direct instruction) pada pembelajaran Bahasa Indonesia memperoleh pancapaian kompetensi siswa, hal ini ditunjukkan pada sajian data pada tabel 2 bahwa 78,78\% siswa sudah memenuhi kriteria ketuntasan belajar secara klasikal. Namun angka tersebut belum cukup untuk mencapai ketuntasan belajar secara klasikal. Meskipun 
begitu ada peningkatan hasil belajar siswa dari siklus sebelum dilakukan siklus I.

Kurangnya hasil belajar ini terjadi karena siswa tersebut tingkat pemahamannya lebih rendah dibanding siswa yang lain dan siswa masih enggan untuk bertanya pada guru saat mengalami kesulitan, sehingga guru harus melakukan perbaikan agar semua siswa dapat memahami materi yang disampaikan oleh guru. Hasil tersebut menggambarkan perlu adanya suatu tahapan selanjutnya untuk memperbaiki hasil belajar agar target yang diharapkan dapat tercapai. Meskipun demikian, terjadi peingkatan hasil belajar siswa dari pra siklus ke siklus I walaupun hasilnya belum sesuai dengan indikator keberhasilan. Hal ini membuktikan bahwa dengan penerapan metode direct instruction dapat meningkatkan hasil belajar siswa Kelas V SD 163086 Tebing Tinggi.

Berdasarkan hasil

pengamatan guru selama melakukan pembelajaran pada siklus I maka dilakukan perbaikan pada siklus II. Hasil siklus II terlihat terjadi peningkatan jika dibandingkan dengan hasil yang diperoleh pada pras siklus dan siklus I. Pada siklus II guru telah mengelola kelas dengan baik sehingga terjadi peningkatan dari siklus sebelumnya. Peningkatan itu dapat terlihat pada proses dan hasil pembelajaran. Pada siklus II meningkat menjadi 30 siswa dengan keaktifan siswa selama pembelajaran mencapai $77,5 \%$ dan persentase ketuntasan belajar sebesar $90,90 \%$.

Sedangkan semua aktivitas siswa pada siklus II yang mengalami peningkatan. Kegiatan siswa dalam menulis kalimat sederhana yang didektekan guru dengan huruf tegak bersambung, menyimak dan mencatat hal-hal yang dianggap penting, membaca lancar 3-5 kalimat yang telah ditulis dengan nyaring, menugaskan siswa menulis dengan huruf tegak sudah dianggap baik oleh peneliti.

Pada siklus II, siswa sudah memahami konsep materi dengan baik. Pembelajaran yang dilaksanakan telah mampu meningkatkan hasil belajar siswa dan telah mencapai kriteria ketuntasan belajar yang diharapkan. Dengan penerapan strategi direct instruction dapat meningkatkan penguasaan materi siswa untuk mata pelajaran. Hal ini terlihat dari perbandingan hasil belajar siswa sebelum pemberian tindakan dengan setelah pemberian tindakan pada siklus I dan siklus II. Peningkatan yang baik dicapai setelah diberikannya tindakan dengan penerapan pembelajaran direct instruction dari siklus I ke siklus II sebesar $15,15 \%$.

Penerapan strategi direct instruction dapat memberikan manfaat yang positif kepada siswa dan juga guru. Peningkatan mutu 
pembelajaran yang tercermin dari hasil belajar siswa dapat dicapai dengan penerapan model pembelajaran ini.

\section{SIMPULAN}

Dari hasil temuan penelitian tentang hasil belajar siswa dengan strategi pembelajaran langsung (direct instruction) di Kelas V SD Negeri 163086 Tebing Tinggi tahun pelajaran 2015/2016 berdampak positif dalam meningkatkan hasil belajar siswa. hasil belajar siswa pada pembelajaran Bahasa Indonesia meningkat dari kondisi prasikus, siklus I dan siklus II. Hal tersebut dapat dilihat dari peningkatan persentase ketuntasan belajar siswa pada pra siklus $(69,69 \%)$, siklus I (78,78 \%), siklus II $(90,90 \%)$.

Atas dasar simpulan dan implikasi hasil penelitian tindakan kelas di atas, penulis memberikan saransaran sebagai berikut :

Bagi Sekolah

Sekolah seyogyanya selalu memperhatikan kualitas pendidikan dengan membiasakan menggunakan model pembelajaran yang variatif, kreatif dan inovatif serta lebih mengusahakan fasilitas yang dapat mendukung kelancaran kegiatan belajar mengajar

Bagi Guru

Jika didalam penelitian terdapat prosedur-prosedur yang harus dilakukan subjek penelitian, guru supaya benar benar memberikan pengertian kepada subjek penelitian agar tidak terjadi kesalahan dalam melaksanakan penelitian.

Siswa diharapkan untuk turut berperan aktif dalam proses pembelajaran di kelas serta agar pembelajaran berhasil.

\section{DAFTAR RUJUKAN}

Amri, S dan Iif Khoiru Ahmadi. 2010. Proses Pembelajaran Kreatif dan Inofatif Dalam Kelas. Jakarta: Prestasi Pustaka Publisher.

Arikunto, Suharsini, Supardi. 2008. Penelitian tindakan Kelas. Jakarta : Bumi Aksara.

Elistina. 2016. Penerapan Model Pembelajaran Langsung (Direct Instruction) Berbantuan Gambar Untuk Meningkatkan Hasil Belajar Siswa Pada Mata Pelajaran IPA di Kelas V SDN 5 Basi Kecamatan Basidondo

Tolitoli. J. Kreatif Tadulako Online Vol. 4 (9).

Hamalik, O. 2003. Kurikulum dan Pembelajaran. Jakarta : Bumi Aksara

I. W. Setaya, I.W. Santyasa, I. M. Kirna. 2015. Penerapan Model Pembelajaran Langsung Berbantuan Pemodelan Untuk Meningkatkan Motivasi dan Prestasi Belajar Renang. J. 
Elmaida: Peningkatan Hasil Belajar...

Program Pascasarjana

Universitas Pendidikan

Ganesha Vol.3

Krisnawati, Md., N.W. Arini, M.

Suarjana. 2015. Penerapan

Pendekatan (PAKEM) Untuk

Meningkatkan Aktivitas dan

Hasil Belajar Bahasa

Indonesia Siswa Kelas VV

SD No.2 Pemaron. Jurnal.

Universitas Pendidikan

Ganesha. Singaraja.

Nana Sudjana. 2009. Penilaian Hasil Proses Belajar

Mengajar. Bandung: PT Remaja Rosdakarya.

Nafsi, A.Z., H. Budiningarti, Martini. 2015. Penerapan Model Direct Instruction Dengan Teknik Mind Mapping Pada Tema Perkaratan Logam Besi Untuk Meningkatkan Hasil Belajar Siswa. J. Pendidikan Sain e-Pensa. Vol. 1(2): 110117.

Rosdiani, Dini. 2012. Model Pembelajaran Langsung Dalam Pendidikan Jasmani dan Kesehatan. Bandung Alfabeta

Sagala, S. 2011. Konsep dan Pembelajaran. Bandung: Alfabeta.
Santoso, A. dkk. 2015. Materi dan Pembelajaran Bahasa Indonesia. Banten : Universitas Terbuka

Slameto. 2003. Belajar dan FaktorFaktor yang Mempengaruhinya. Jakarta: PT Rineka Cipta.

Sudjana, N. 2010. Penilaian Hasil Proses Belajar Mengajar. Bandung : PT. Remaja Rosda Karya

Trianto. 2009. Mengembangkan Model Pembelajaran Tematik. Jakarta: Prestasi Pustaka.

Zubaidah, Siti. 2010. Restrukturisasi Pemahaman Berbagai Istilah Pada Penulisan Komponen Metode Dalam Rencana Pelaksanaan Pembelajaran, (online), (http://teqip.com/download/jt eqip/jurnal- 20-37.pdf, diakses 10 Mei 2015). 